\title{
The effect of feeding fresh swine manure, poultry waste, urea, molasses and bakery by-products ensiled for lambs
}

\author{
Fernando Martínez San Pedro ${ }^{1}$ Ignacio A. Domínguez Vara ${ }^{1} \cdot$ José Luis Bórquez $^{1}$ • \\ Manuel Gonzalez-Ronquillo ${ }^{1}$ (B)
}

Received: 16 April 2015/Accepted: 5 October 2015/Published online: 7 November 2015

(C) The Author(s) 2015. This article is published with open access at Springerlink.com

\begin{abstract}
Introduction The use of by-products such as swine manure $(\mathrm{SM})$, poultry waste $(\mathrm{PW})$, urea $(\mathrm{U})$, molasses (M) and bakery by-product (BB) is an alternative method for lamb feeding. The objective of the present study was to determine the chemical composition, dry matter intake and digestibility in growing lambs using ensiled PW combined with BB (PWBB), SM with BB (SMBB), SM with M (SMM) and $\mathrm{U}$ with $\mathrm{M}(\mathrm{UM})$ in their diets.

Methods Four silages-PWBB, SMBB, SMM and UMwere prepared, the chemical composition of the silages was determined $(n=3)$, silages and concentrate ratio (60:40) as fresh matter were given to growing lambs over 21 days as total period, and the collection of samples to determine intake and digestibility was carried out for the last 7 days, in a $4 \times 4$ Latin square design, with a significance level $P<0.05$.

Results The organic matter $(\mathrm{OM})$ was lower $(P<0.05)$ in silage with SMM $(886 \mathrm{~g} / \mathrm{kg})$, and crude protein increased with UM (206 g/kg) followed by PWBB (170 g/ $\mathrm{kg})$. DM, OM, NDF and ADF intake was higher $(P<0.05)$ in UM diets compared with the rest of the treatments; ADF digestibility was lower $(P<0.05)$ for SMM $(389 \mathrm{~g} / \mathrm{kg})$ than UM $(417 \mathrm{~g} / \mathrm{kg})$ diets. $\mathrm{N}$ intake was higher $(P<0.05)$ in $\mathrm{UM}(51.3 \mathrm{~g} \mathrm{~N} /$ day $)$ diets than the rest of the treatments $(39.9 \pm 1.3 \mathrm{~g} \mathrm{~N} /$ day).

Conclusions The use of PWBB, SM combined with BB or $\mathrm{M}$ is an alternative method for lamb feeding, provided
\end{abstract}

Manuel Gonzalez-Ronquillo

mrg@uaemex.mx

1 Departamento de Nutrición Animal, Facultad de Medicina Veterinaria y Zootecnia, Universidad Autónoma del Estado de México, CP 50000 Toluca, Edo de México, México that a proper formulation supplies the nutrient requirements of crude protein and diminish the $\mathrm{N}$ excretion compared with UM diet.

Keywords Poultry waste $\cdot$ Fresh pig manure . Bakery by-product $\cdot$ Silage $\cdot$ Lambs

\begin{tabular}{ll}
\multicolumn{2}{l}{ Abbreviations } \\
ADF & Acid detergent fiber \\
BB & Bakery by-product \\
DM & Dry matter \\
M & Molasses \\
ME & Metabolizable energy \\
N & Nitrogen \\
NDF & Neutral detergent fiber \\
NPN & Non-protein N \\
OM & Organic matter \\
PW & Poultry waste \\
SM & Swine manure \\
U & Urea
\end{tabular}

\section{Introduction}

The sustainability of animal diets is crucial in the development of livestock production systems, and feed efficiency can be improved by reusing food waste (i.e. bakery by-products, residues of the sugar industry, pineapple and citrus by-products) in ruminant diets, thus diminishing the use of food grains (Makkar and Ankers 2014).

The use of excretes from livestock is an alternative method of supplying non-protein nitrogen (NPN) in the feed of ruminants (Ortiz et al. 2007; Nasiru et al. 2014); 
however, they usually have low energy content for optimal rumen bacteria growth. The use of by-products from the baking and sugar industries provides an attractive energy source for ruminants. Increased cellulolytic activity of microorganisms in the rumen can increase the digestible energy due to better utilization of fibrous feeds, and otherwise improve the supply of microbial protein (Chandrasekharaiah et al. 2012). Several studies (Bórquez et al. 2009; Trujillo et al. 2014) have proved that the inclusion of up to $50 \%$ silage manure as dry matter does not affect the intake and metabolic response in lambs, thus presenting an option as a sustainable resource in ruminant feeding.

The aim of this study was to evaluate the effects of swine manure (SM), poultry waste (PW) and urea (U) as nitrogen sources, with the inclusion of molasses (M) or bakery by-product (BB) as carbohydrate sources, on the chemical composition of silages and their intake and digestibility in lambs.

\section{Materials and methods}

\section{Experimental silages and chemical analysis}

Four silages were prepared using nitrogen (SM, PW and U) and energy sources ( $\mathrm{M}$ and $\mathrm{BB}$ ), and mixed with corn stover in different proportions as a fiber source (Table 1).
The silages were prepared with $\mathrm{PW}$ combined with $\mathrm{BB}$ (PWBB), SM with BB (SMBB), SM with M (SMM) and U with $\mathrm{M}$ (UM). Each combination was ensiled with a bacterial additive (Sill-All $4 \times 4$ Alltech $^{\circledR}, 10 \mathrm{mg} / \mathrm{kg} \mathrm{DM}$; Streptococcus faecium, Lactobacillus plantarum, Pediococcus acidilactici and Lactobacillus salivarius and enzymes cellulase, hemicellulase, pentosanase and amylase). The mixing process was performed by adding water (480 $\mathrm{ml} / \mathrm{kg}$ fresh matter) to SM, PW and U, followed by M or BB. Once diluted, these combinations were mixed with corn stover in different proportions in plastic bags with a capacity of $50 \mathrm{~kg}$, in three replications, compacted and sealed to prevent the ingress of air; for details see MejíaUribe et al. (2013).

After 60 days, the silage bags were opened (SerranoGarcía et al. 2008) and samples of $500 \mathrm{~g}$ were taken from each bag; $\mathrm{pH}$ was determined with a $\mathrm{pH}$ meter (Conductronic $\mathrm{pH} 130$ ), samples were dried in a forced air oven $\left(60{ }^{\circ} \mathrm{C}, 48 \mathrm{~h}\right)$ and grounded in a Willey mill $(2 \mathrm{~mm}$ diameter). Silage samples were analyzed for dry matter (DM, \#934.01), ash (\#942.05) and N (\#954.01) according to AOAC (1997). Neutral and Acid detergent fiber (NDF and ADF; Van Soest et al. 1991) were analyzed using an ANKOM200 Fiber Analyzer Unit (ANKOM Technology Corporation, Macedon, NY, USA), and lignin (AOAC 1997; \#973.18). NDF was assayed with alpha amylase and sodium sulfite in the NDF. Both NDF and ADF are
Table 1 Proportion of the ingredients and chemical composition $(\mathrm{g} / \mathrm{kg} \mathrm{DM})$ of the experimental silages

\begin{tabular}{lllllll}
\hline Ingredient/silage & PWBB & SMBB & SMM & UM & SEM & $P$ value \\
\hline Poultry waste & 384 & & & & & \\
Swine manure & & 250 & 274 & & \\
Urea & & & 64 & & \\
Bakery by-product & 231 & 281 & & & & \\
Molasses & & & 214 & 262 & & \\
Corn stover & 385 & 469 & 512 & 674 & & \\
Additive & 0.01 & 0.01 & 0.01 & 0.01 & & \\
Total & 1000 & 1000 & 1000 & 1000 & & \\
Chemical composition & & & & & & \\
pH & $4.54 \mathrm{a}$ & $4.72 \mathrm{a}$ & $3.93 \mathrm{a}$ & $6.52 \mathrm{~b}$ & 0.7 & 0.01 \\
Dry matter & $359 \mathrm{bc}$ & $357 \mathrm{bc}$ & $338 \mathrm{c}$ & $408 \mathrm{a}$ & 5.1 & 0.01 \\
Organic matter & $913 \mathrm{~b}$ & $921 \mathrm{a}$ & $886 \mathrm{c}$ & $920 \mathrm{ab}$ & 2.3 & 0.01 \\
Crude protein & $170 \mathrm{bc}$ & $161 \mathrm{c}$ & $147 \mathrm{c}$ & $206 \mathrm{ab}$ & 6.0 & 0.01 \\
Neutral detergent fiber & $529 \mathrm{c}$ & $524 \mathrm{cb}$ & $511 \mathrm{~b}$ & $485 \mathrm{a}$ & 7.7 & 0.03 \\
Acid detergent fiber & 263 & 255 & 241 & 255 & 6.8 & 0.47 \\
Lignin & 39 & 39 & 38 & 39 & 1.5 & 0.58 \\
\hline
\end{tabular}

abc Different letters indicate significance $(P<0.05)$

$P W$ poultry waste, $S M$ swine manure, $U$ urea, $B B$ bakery by-product, $M$ molasses, $S E M$ standard error of mean

${ }^{\text {a }}$ Additive sill all $4 \times 44^{\circledR}(10 \mathrm{mg} / \mathrm{kg} \mathrm{DM})$

b Dry matter expressed as fresh matter 
expressed without residual ash. Moisture content of the silages was determined through distillation with toluene (Haigh and Hopkins 1977).

\section{Animals and diets}

Four Hampshire lambs with live weight (LW) of $30 \pm 3.0 \mathrm{~kg}$ and $<1$ year old, provided with ruminal cannulas, were fed with the four experimental silages using a $4 \times 4$ Latin square design. The animals were placed in metabolic cages. The diet consisted of the inclusion of silages (Table 1) and concentrate supplement (Table 2) in order to meet growth requirements (NRC 2007). At the beginning of the experiment, animals were dewormed (IVOMEC $^{\circledR}$; Ivermectin $1 \mathrm{ml} 50 \mathrm{~kg} \mathrm{LW}$ ), supplemented with ADE complex ( $1 \mathrm{ml} / \mathrm{head} \mathrm{IM})$ and vaccinated (Bobact $8^{\circledR}, 2.5 \mathrm{ml} /$ animal). The experimental diets were formulated to contain approximately $140 \mathrm{~g} / \mathrm{kg} \mathrm{CP}$ and $10.25 \mathrm{MJ}$ $\mathrm{ME} / \mathrm{kg} \mathrm{DM}$ on average; treatments were administered ad libitum twice a day at 08.00 and $16.00 \mathrm{~h}$. Each experimental period lasted 21 days, allowing 14 days for

Table 2 Proportion of the ingredients used and chemical composition $(\mathrm{g} / \mathrm{kg} \mathrm{DM})$ of the diets for growing lambs, with the inclusion of silages of poultry waste $(\mathrm{PW})$, swine manure $(\mathrm{SM})$ or urea $(\mathrm{U})$ with the inclusion of bakery by-product (BB) or molasses (M)

\begin{tabular}{|c|c|c|c|c|}
\hline Ingredients & PWBB & SMBB & SMM & UM \\
\hline Experimental silages & 376 & 374 & 360 & 406 \\
\hline Corn stover & 178 & 260 & 221 & 241 \\
\hline Soybean meal $44 \% \mathrm{CP}$ & 27 & 28 & 28 & 0 \\
\hline Corn grain & 275 & 195 & 244 & 243 \\
\hline Wheat bran & 71 & 71 & 73 & 54 \\
\hline Fish meal & 30 & 30 & 31 & 23 \\
\hline Vitamin and mineral premix ${ }^{a}$ & 43 & 42 & 43 & 33 \\
\hline \multicolumn{5}{|l|}{ Chemical composition } \\
\hline Dry matter & 556 & 546 & 524 & 685 \\
\hline Organic matter & 940 & 939 & 929 & 941 \\
\hline Crude protein & 141 & 134 & 130 & 140 \\
\hline Rumen degradable protein & 86 & 88 & 85 & 102 \\
\hline Neutral detergent fiber & 417 & 471 & 435 & 452 \\
\hline Acid detergent fiber & 212 & 250 & 222 & 245 \\
\hline Lignin & 34 & 41 & 37 & 40 \\
\hline $\mathrm{ME}(\mathrm{MJ} / \mathrm{kg} \mathrm{DM})$ & 10.25 & 10.25 & 10.25 & 10.25 \\
\hline Calcium & 7.6 & 9.0 & 11.8 & 7.9 \\
\hline Phosphorus & 6.5 & 6.0 & 6.2 & 6.1 \\
\hline
\end{tabular}

DM is dry matter expressed as fresh matter, ME is metabolizable energy expressed as $\mathrm{MJ} / \mathrm{kg} \mathrm{DM}$

${ }^{a}$ Content of vitamin/mineral premix $/ \mathrm{kg}$ : $60 \mathrm{~g}$ phosphorus; $160 \mathrm{~g}$ calcium; $100 \mathrm{~g}$ sodium; $20 \mathrm{~g}$ potassium; $4 \mathrm{~g}$ sulfur; $2 \mathrm{~g}$ magnesium; $30 \mathrm{mg}$ zinc; $0.6 \mathrm{mg}$ copper; $1.8 \mathrm{mg}$ iron; $2 \mathrm{mg}$ manganese; $20 \mathrm{mg}$ iodine; $6 \mathrm{mg}$ cobalt; $12 \mathrm{mg}$ selenium; $50000 \mathrm{IU}$ vitamin A; 10 000 IU vitamin $\mathrm{D} ; 250$ IU vitamin $\mathrm{E}$ adaptation to the diet and 7 days for sample collection. Feed and ort samples were collected on days 14 to 21 , weighed and composited daily, both for each individual sheep and across days. Total fecal matter and urine were weighed and sub-sampled (10\% of wet weight) for each lamb and period and stored at $-20{ }^{\circ} \mathrm{C}$ for laboratory analysis.

On day 21 , ruminal fluid samples $(250 \mathrm{ml})$ were drawn using a suction strainer, obtained via ruminal cannula at 0 (previous ingestion), 3, 6, 9 and $12 \mathrm{~h}$ after feeding. Samples were filtered through a double layer of cheesecloth gauze, and the $\mathrm{pH}$ was recorded (Conductronic $\mathrm{pH} 130$ ).

\section{Statistical analysis}

Chemical composition data were processed as a complete randomized design (Steel et al. 1997), using the following model:

$Y_{i j}=\mu+T_{i}+\varepsilon_{i j}$,

where $Y_{i j}$ is the response variable, $\mu$ is the general mean, $T_{i}$ is the effect due to diet and $\varepsilon_{i j}$ is the random experimental error.

The in vivo experiment data were analyzed according to a $4 \times 4$ Latin square design, following the model:

$Y_{i j k}=\mu+T_{i}+A_{j}+P_{k}+\varepsilon_{i j k}$

where $Y_{i j}$ is the response variable, $\mu$ is the general mean, $T_{i}$ is the effect due to diet, $A_{j}$ is the animal effect, $P_{k}$ is the effect due to experimental period, and $\varepsilon_{i j k}$ is the random experimental error. The GLM procedure of SAS (2002) was used. The means of treatments were compared by Tukey's test (Steel et al. 1997) where the effect was significant $(P \leq 0.05)$.

\section{Results}

\section{Chemical composition of silages}

Silage $\mathrm{pH}$ was higher for UM $(P<0.001)$ compared with the rest of the treatments (Table 2); the OM content was higher $(P<0.001)$ for SMBB and UM, followed by PWBB compared with SMM. The CP concentration was higher $(P<0.001)$ for UM than SMBB and SMM. There were no differences $(P>0.05)$ for ADF and lignin among silages. The NDF content was higher $(P<0.03)$ for PWBB and SMBB than UM. The inclusion of experimental silages (Table 2) in the diets ranged from 360 to $406 \mathrm{~g} / \mathrm{kg} \mathrm{DM}$, and the $\mathrm{CP}$ of the diets varied from 130 to $141 \mathrm{~g} / \mathrm{kg}$, being lower for SMBB and SMM. The NDF and ADF content in the diets were lower in PWBB and SMM compared with SMBB and UM diets. 


\section{Nutrient intake and digestibility}

Table 3 shows the $\mathrm{pH}$, intake, digestibility and nitrogen balance in growing lambs fed manure silage. By far the most effective source of nitrogen and minerals (ash) was provided by the livestock manure (swine and poultry), urea as we know, is only a source of nitrogen. Ruminal $\mathrm{pH}$ values in lambs were similar $(P>0.05)$. The DM, OM and ADF intakes were higher $(P<0.05)$ for silage based on UM compared with the rest of the treatments. The NDF intake was higher $(P<0.05)$ for UM, followed by PWBB and SMM, and lower for SMBB. Digestibility of DM, OM and NDF was similar among treatments $(P>0.05)$. The ADF digestibility was lower $(P<0.05)$ for SMM compared with UM treatment. Nitrogen intake (g N/day) was higher $(P<0.05)$ for UM compared with the rest of the treatments. Nitrogen excretion (feces and urine) and retention were similar among treatments $(P>0.05)$.

\section{Discussion}

\section{Chemical composition of silages}

All the silages had acceptable quality (Frenkel 1984), except UM, which showed higher $\mathrm{pH}$ values (Table 1). This might be due to the fact that BBP and $\mathrm{M}$ were a better carbohydrate sources to be fermented into desirable organic acids such as lactic, acetic and propionic acids, diminishing the $\mathrm{pH}$. The low $\mathrm{pH}$ in silages in our study suggests that undesirable fecal microorganisms (Coliforms, Salmonella, Shigella, Proteus), yeasts and molds may had been eliminated (Pagán et al. 2014; Serrano-García et al. 2008), which have been reported for cattle manure 1 week after ensiling (Cornman et al. 1981; McCaskey and Wang 1983). Optimum moisture recommended for manureblended silage is at least $600 \mathrm{~g} / \mathrm{kg}$ (McCaskey and Wang 1983), whereas in our study moisture of silages ranged from 524 to $685 \mathrm{~g} / \mathrm{kg}$. Bórquez et al. (2009) using cattle manure silage with BB, the amount of DM was lower with respect to which was added $M$. The amount of water varies among the different ingredients added in the silages, thus varying among silages. The $\mathrm{CP}$ and $\mathrm{NDF}$ content can vary depending on the type and amount of bedding floor used by the livestock species (Tobia and Vargas 2000). Evans and Smith (1986) reported that the use of U leads to changes in cell wall components of forages treated, destroying the linkages of phenolic groups between hemicellulose and lignin, which solubilizes the hemicellulose and make it available to the cell wall unless UM silage includes more corn stover than the rest of the silages. Tobia and Vargas (2000) found a similar protein content in PW and NDF, but higher for ADF. Mthiyane et al. (2001) showed a lower content of CP and OM compared with the present study, but higher in NDF for PW. These variations in nutrient content depend on the type of food, floor and management of excreta that is offered to poultry and pigs (Tobia and Vargas 2000; Morales et al. 2002; Teixeira et al. 2015),
Table 3 Intake $\left(\mathrm{g} / \mathrm{kg} \mathrm{LW} \mathrm{L}^{0.75}\right)$, digestibility $(\mathrm{g} / \mathrm{kg})$ and $\mathrm{N}$ balance (g/day) in lambs fed with silages of poultry waste $(\mathrm{PW})$, swine manure (SM) or urea $(\mathrm{U})$ with the inclusion of bakery by-product (BB) or molasses (M)

\begin{tabular}{lllllll}
\hline Item & PWBB & SMBB & SMM & UM & SEM & $P$ value \\
\hline Rumen pH & 6.63 & 6.46 & 6.62 & 6.83 & 0.09 & 0.37 \\
Intake $\left(\mathrm{g} / \mathrm{kg} \mathrm{LW} \mathrm{LW}^{0.75}\right.$ ) & & & & & & \\
Dry matter & $77.7 \mathrm{~b}$ & $77.9 \mathrm{~b}$ & $79.2 \mathrm{~b}$ & $88.0 \mathrm{a}$ & 1.73 & 0.01 \\
Organic matter & $68.7 \mathrm{~b}$ & $70.0 \mathrm{~b}$ & $70.4 \mathrm{~b}$ & $78.6 \mathrm{a}$ & 1.65 & 0.01 \\
Neutral detergent fiber & $40.7 \mathrm{c}$ & $38.2 \mathrm{c}$ & $43.0 \mathrm{~b}$ & $47.9 \mathrm{a}$ & 1.65 & 0.01 \\
Acid detergent fiber & $34.2 \mathrm{~b}$ & $32.9 \mathrm{~b}$ & $34.6 \mathrm{~b}$ & $40.4 \mathrm{a}$ & 1.70 & 0.01 \\
Digestibility (g/kg) & & & & & & \\
Dry matter & 718 & 675 & 681 & 674 & 31.90 & 0.52 \\
Organic matter & 728 & 722 & 687 & 717 & 18.30 & 0.56 \\
Neutral detergent fiber & 525 & 538 & 501 & 537 & 8.50 & 0.48 \\
Acid detergent fiber & $402 \mathrm{ab}$ & $396 \mathrm{ab}$ & $389 \mathrm{~b}$ & $417 \mathrm{a}$ & 5.70 & 0.05 \\
$\mathrm{~N}$ balance (g/day) & & & & & & \\
$\mathrm{N}$ intake & $40.7 \mathrm{~b}$ & $38.5 \mathrm{~b}$ & $40.6 \mathrm{~b}$ & $51.3 \mathrm{a}$ & 1.36 & 0.05 \\
$\mathrm{~N}$ excretion & & & & & & \\
$\quad \mathrm{N}$ feces & 13.0 & 12.9 & 15.3 & 13.8 & 1.32 & 0.35 \\
$\quad \mathrm{~N}$ urine & 11.7 & 10.8 & 10.9 & 14.9 & 1.61 & 0.42 \\
$\mathrm{~N}$ retention & 16.1 & 15.7 & 14.4 & 22.5 & 1.84 & 0.34 \\
\hline
\end{tabular}

abc Different letters indicate significance $(P<0.05)$

$S E M$ standard error of mean 
effecting a wide variation in the chemical composition of PW and SM.

\section{Nutrient intake and digestibility}

The inclusion level of silage in the diet had no effect on ruminal $\mathrm{pH}$ in the lambs (Table 3 ), which could be due to silage inclusion which ranged around $60 \%$ as fresh matter and there was a sufficient amount of NDF in the entire diet (ranging 417-471 g/kg DM). The intake of DM, OM, NDF and ADF was similar to Trujillo et al. (2014). The digestibility ( $\mathrm{g} / \mathrm{kg}$ ) of DM and OM based on PW silage was lower than Morales and Egaña (1997), but similar for NDF digestibility; these variations depend on the chemical composition of the different poultry waste sources. In the present study, there were no differences $(P>0.05)$ among DM, OM and NDF digestibility, which was similar to Obeidat et al. (2011) and Trujillo et al. (2014), but ADF digestibility was higher $(P<0.05)$ for UM compared with SMM. This effect could be related with the lower ADF intake and higher ash content in the SMM diet, as was found by Jakhmola et al. (1988) and Iñiguez-Covarrubias et al. (1990).

The lower $\mathrm{N}$ intake in the silage diets compared with the UM diet is a direct response to the higher DM intake in the UM diet compared with the rest of the silages; the $\mathrm{N}$ retained in lambs fed diets with the inclusion of PW and SM silage was numerically lower $(P=0.34)$ than UM, which provided more efficient $\mathrm{N}$ retention in the animals. The inclusion level of silages in the diets of up to $37 \%$ neither enhanced nor adversely affected animal performance as compared with UM, which are in agreement with the results of Zia-ul-Hassan et al. (2011) and Sarwar et al. (2011) in feeding traits with different levels of cattle manure in lactating Nili-Ravi buffaloes and growing cattle calves, respectively; and with Trujillo et al. (2014) who studied different levels of SM or PW silages in growing lambs.

\section{Conclusion}

UM silage showed higher $\mathrm{pH}$ and DM, OM, CP content, but lower NDF. Treatment with these silage also showed higher DM, OM, NDF and ADF intake. Nitrogen intake was higher with la inclusion of UM silage, but there was no difference in $\mathrm{N}$ retention. It is concluded that UM silage inclusion in complete diets for growing lambs can be as good as the use of livestock manures silages.

Acknowledgments Mr. Martinez San Pedro was granted for a CONACyT fellowship during his studies in the University Autonomous State of Mexico. This study was supported by the project
UAEMex 2238/2006 and 2750/2009. Dr. González was granted for a CONACyT fellowship (Estacias Sabaticas en el Extranjero, 2014), also we thanks to Miss. Penelope Krumm for the critical review of this paper.

Author contribution All authors have made reasonable effort on all parts of the work necessary for the development of this manuscript in accordance with their expertise. All authors read and approved the final manuscript.

\section{Compliance with ethical standards}

Conflict of interest The authors declare they have no conflicts of interest with regard to the work presented in this report.

Open Access This article is distributed under the terms of the Creative Commons Attribution 4.0 International License (http://crea tivecommons.org/licenses/by/4.0/), which permits unrestricted use, distribution, and reproduction in any medium, provided you give appropriate credit to the original author(s) and the source, provide a link to the Creative Commons license, and indicate if changes were made.

\section{References}

AOAC (Association of Official Analytical Chemists) (1997) Official methods of analysis, 16th edn. AOAC, Arlington

Bórquez JL, Gonzalez Muñoz SS, Pinos Rodriguez JM, Dominguez I, Barcena JR, Mendoza GD, Cobos MA, Bueno G (2009) Feeding value of ensiling fresh cattle manure with molasses or bakery by products in lambs. Lives Sci 122:276-280

Chandrasekharaiah M, Thulasi A, Sampath KT (2012) Effect of different rumen degradable nitrogen levels on microbial protein synthesis and digestibility in sheep fed on finger millet straw (Eleucine coracana) based diet. Small Rum Res 102:51-156

Cornman AW, Lamm WD, Webb KE, Fontenot JP (1981) Ensiling cattle waste with rye straw as a diet supplement for ruminants. J Anim Sci 52:1233-1239

Evans MR, Smith MPW (1986) Treatment of farm animal wastes. J Appl Bact 61(Suppl.):27S-41S

Frenkel MA (1984) Forage conservation: hays, silages, dehydration. Albatros, Buenos Aires

Haigh PM, Hopkins JR (1977) Relationship between oven and toluene dry matter in grass silage. J Sci Food Agric 28(6):477-480

Iñiguez-Covarrubias G, Cuarón-Ibargüengoitia JA, Pérez-Gavilán P, de la Torre-Martinez M, Magaña Plaza I (1990) Fermentation characteristics, digestibility and performance of ensiled swine waste, wheat straw and cane molasses fed to sheep. Biol Wastes 34(4):281-299

Jakhmola RC, Kundu SS, Punj ML, Singh Kiran, Kamra DN, Singh Rameshwar (1988) Animal excreta as ruminant feed-Scope and limitations under Indian conditions. Anim Feed Sci Technol 19:1-23

Makkar HPS, Ankers P (2014) Towards sustainable animal diets: a survey-based study. Anim Feed Sci Technol 198:309-322

McCaskey TA, Wang YD (1983) Microflora and acid development of rations ensiled with varied percents of bovine manure and moisture. J Dairy Sci 66:93-98

Mejía-Uribe LA, Bórquez JL, Salem AZM, Dominguez IA, González-Ronquillo M (2013) Effects of adding different protein and carbohydrates sources on chemical composition and in vitro gas production of corn stover silage. Spanish J Agric Res 11(2):427-430 
Morales MS, Egaña JI (1997) Efecto del peletizado y ensilaje de las camas de broiler sobre su valor nutritivo para rumiantes. 1. Evaluación nutricional y productiva. Arch Zoot 46:159-167

Morales TH, Gutierrez HE, Bernal BH (2002) El uso de la cama de pollo de buena calidad mejora la productividad de bovinos en crecimiento en engorda intensiva. Tec Pec México 40:1-15

Mthiyane DMN, Nsahlai IV, Bonsi MLK (2001) The nutritional composition, fermentation, characteristics, in sacco degradation and fungal pathogen dynamics of sugarcane tops ensiled with broiler litter with or without water. Anim Feed Sci Technol 94:171-185

Nasiru A, Ibrahim MH, Ismail N (2014) Nitrogen losses in ruminant manure management and use of cattle manure vermicast to improve forage quality. Int J Recycl Org Waste Agric 3:57

NRC (2007) National Research Council: nutrient requirements of small ruminants: sheep, goats, cervids and new world camelids. National Academy Press, Washington, DC

Obeidat BS, Awawdeh MS, Abdullah AY, Muwalla MM, Abu Ishmais MA, Telfah BT, Ayrout AJ, Matarneh SK, Subih HS, Osaili TO (2011) Effects of feeding broiler litter on performance of Awassi lambs fed finishing diets. Anim Feed Sci Technol 165:15-22

Ortiz RMA, Orskov ER, Milne J, Galina HMA (2007) Effect of different sources of nitrogen on in situ degradability and feed intake of zebu cattle fed sugarcane tops (Saccharum officinarum). Anim Feed Sci Technol 139:143-158

Pagán S, Rodríguez AA, Valencia EM, Randel PF (2014) Pineapple and citrus silage as potential feed for small ruminant diets: fermentation characteristics, intake, nutrient digestibility, and aerobic stability. Rev Colomb Cienc Pecu 27:37-46

Sarwar M, Shahzad M, Nisa M, Afzal D, Sharif M, Saddiqi H (2011) Feeding value of urea molasses-treated wheat straw ensiled with fresh cattle manure for growing crossbred cattle calves. Trop Anim Health Prod 3(3):543-548. doi:10.1007/s11250-010-9745-5

SAS (2002) Statistical analysis system institute. User's guide: statistic version 9. SAS Institute Inc., Cary

Serrano-García E, Castrejón-Pineda F, Herradora-Lozano MA, Ramírez-Pérez AH, Angeles-Campos S, Buntinx SE (2008) Fungal survival in ensiled swine faeces. Bioresour Technol 99:3850-3854

Steel RGD, Torrie TH, Dickey DA (1997) Principles and procedures of statistics o biometrical approach, 2nd edn. Mc Graw Hill Book Co., New York

Teixeira AS, de Oliveira MC, Menezes JFS, Gouvea BM, Teixeira SR, Gomes AR (2015) Poultry litter of wood shavings and/or sugarcane bagasse: animal performance and bed quality. Rev Colomb Cienc Pecu 28(3):238-246

Tobia C, Vargas E (2000) Evaluación de las excretas de pollos de engorde (pollinaza) en la alimentación animal. 1. Disponibilidad y Composición química. Agronomia Costarricence 24(1):47-53

Trujillo GD, Bórquez GJL, Pinos-Rodríguez JM, Domínguez-Vara IA, Rojo RR (2014) Nutritive value of ensiled pig excreta, poultry litter or urea with molasses or bakery by-products in diets for lambs. South Afr J Anim Sci 44(2):114-122. doi:10. 4314/sajas.v44i2.3

Van Soest PJ, Robertson JB, Lewis BA (1991) Methods for dietary fiber neutral detergent fibre and non starch polysaccharides in relation to animal nutrition. J Dairy Sci 74:3583-3597

Zia-ul-Hassan M, Aasif Shahzad, Nisa M, Sarwar M (2011) Nutrient utilization and milk yield response of early lactating NiliRavi buffaloes fed on urea-molasses treated wheat straw fermented with cattle manure. Livest Sci 139:271-276 